AL. 2.1998 .73

C. 2

\title{
Common Winter Annual Weeds in Alberta
}

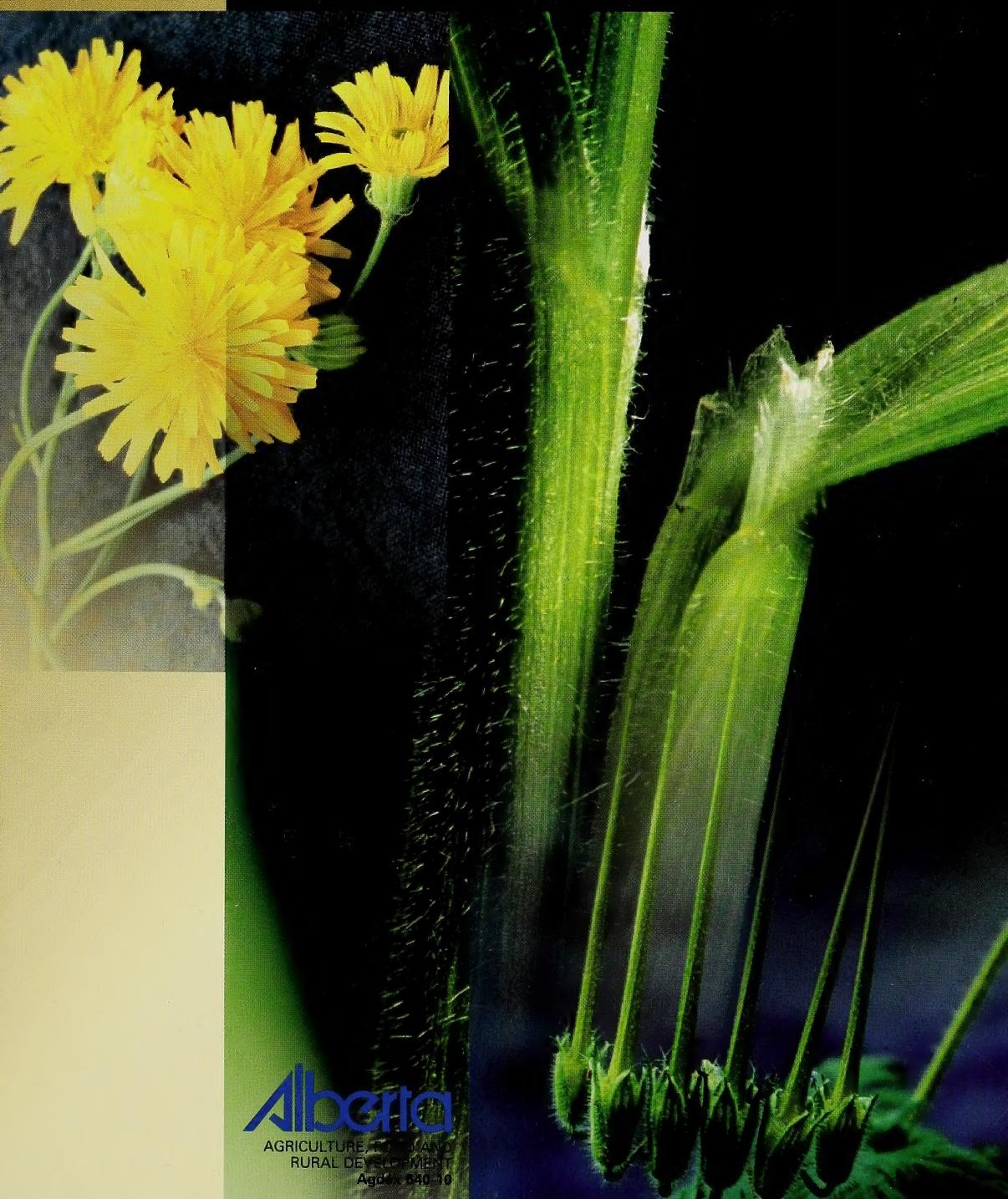





\section{Common Winter Annual Weeds in Alberta}

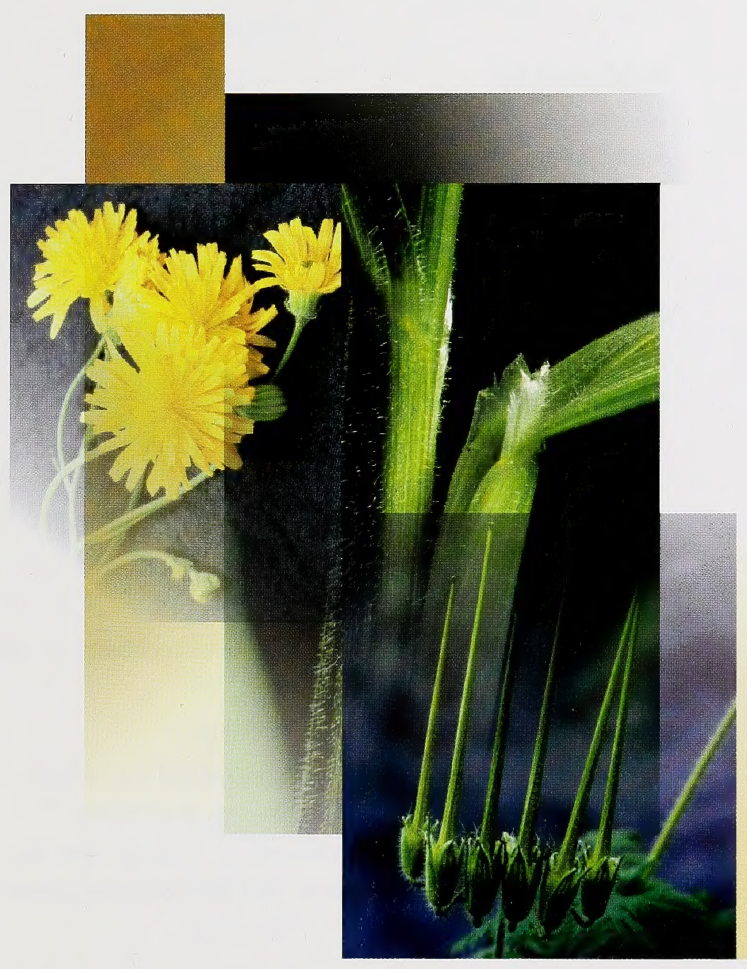

MAY 221998 


\section{Published by:}

Alberta Agriculture, Food and Rural Development

Publishing Branch

7000 - 113 Street

Edmonton, Alberta T6H 5 T6

Editor: C.R. King

Electronic Publishing Production: Carolyn Boechler

Print Coordinator: Chris Kaulbars

Graphic Designer: John Gillmore

Funding for printing this publication was provided by the Alberta Environmentally Sustainable Agriculture Program.

(C) Copyright 1997. Her Majesty the Queen in Right of Alberta. All rights reserved.

No part of this publication may be reproduced, stored in a retrieval system or transmitted in any form or by any means, electronic, mechanical, photocopying, or otherwise without permission from the Publishing Branch, Alberta Agriculture, Food and Rural Development.

Printed 199708 2M 


\section{Contents}

Acknowledgements $\ldots \ldots \ldots \ldots \ldots \ldots \ldots$ ii

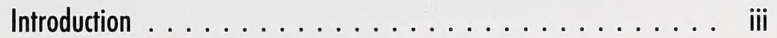

Glossary $\ldots \ldots \ldots \ldots \ldots \ldots \ldots \ldots$ iv

Ball mustard $\ldots \ldots \ldots \ldots \ldots \ldots \ldots \ldots$

Bluebur .................... 2

Chickweed $\ldots \ldots \ldots \ldots \ldots \ldots \ldots \ldots \ldots \ldots$

Common groundsel . . . . . . . . . . . . . . 4

Common pepper-grass $\ldots \ldots \ldots \ldots \ldots \ldots \ldots$

Dog mustard $\ldots \ldots \ldots \ldots \ldots \ldots \ldots$

Downy brome . . . . . . . . . . . . . . 7

Flixweed $\ldots \ldots \ldots \ldots \ldots \ldots \ldots \ldots \ldots$

Knawel $\ldots \ldots \ldots \ldots \ldots \ldots \ldots \ldots \ldots$

Narrow-leaved hawk's-beard $\ldots \ldots \ldots \ldots \ldots$

Night-flowering catchfly $\ldots \ldots \ldots \ldots \ldots \ldots$

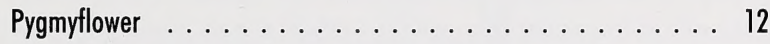

Scentless chamomile . . . . . . . . . . . . 13

Shepherd's-purse . . . . . . . . . . . . . . . 14

Stinkweed . . . . . . . . . . . . . . . . 15

Stork's-bill $\ldots \ldots \ldots \ldots \ldots \ldots \ldots \ldots \ldots \ldots$

Yellow whitlow-grass $\ldots \ldots \ldots \ldots \ldots \ldots \ldots \ldots$ 


\section{Adnowledgements}

he authors would like to thank Debbie Bigelow, Department of Agriculture, Food and Nutritional Science, University of Alberta, and the Direct Seeding Editorial Board (Robert Dunn, Murray Hartman, leuan Evans and Murray Green), Alberta Agriculture, Food and Rural Development, for their valuable review comments.

We also thank the following people for providing photographs for this booklet: Beth Hoar/Alberta Agriculture, Food and Rural Development, France Royer/Sundew Productions Ltd., Rick Holm/University of Saskatchewan, Sue McColl/University of Saskatchewan, Carol Bubar/Olds College, Ian Morrison/University of Alberta and Robert Dunn/Alberta Agriculture, Food and Rural Development.

\section{Photo credits}

Ball mustard: seedling, Alberta Agriculture, Food and Rural Development; juvenile, Hoar; adult, Hoar; flower, Hoar

Bluebur: seedling, Royer; juvenile, Royer; adult, Hoar; flower, Hoar

Chickweed: seedling, Hoar; juvenile, Holm; adult, Alberta Agriculture, Food and Rural Development; flower, Alberta Agriculture, Food and Rural Development

Common groundsel: seedling, Alberta Agriculture, Food and Rural Development; juvenile, Hoar; adult, Hoar; flower, Alberta Agriculture, Food and Rural Development

Common pepper-grass: seedling, Royer; juvenile, Royer; adult, Hoar; flower, Holm

Dog mustard: seedling, McColl; juvenile, McColl; adult, Holm; flower, Bubar

Downy brome: seedling, Royer; juvenile, Hoar; adult, Agriculture and Agri-Food Canada; flower, Hall

Flixweed: seedling, Holm; juvenile, Alberta Agriculture, Food and Rural Development; adult, Alberta Agriculture, Food and Rural Development; flower, Hoar

Knawel: seedling, Royer; juvenile, Alberta Agriculture, Food and Rural Development; adult, Hoar; flower, Hoar

Narrow-leaved hawk's-beard: seedling, Alberta Agriculture, Food and Rural Development; juvenile, Royer; adult, Hall; flower, Hoar

Night-flowering catchfly: seedling, Alberta Agriculture, Food and Rural Development; juvenile, Holm; adult, Morrison; flower, Alberta Agriculture, Food and Rural Development

Pygmyflower: seedling, Dunn; juvenile, Hoar; adult, Dunn; flower, Hoar

Scentless chamomile: seedling, Alberta Agriculture, Food and Rural Development; juvenile, Alberta Agriculture, Food and Rural Development; adult, Alberta Agriculture, Food and Rural Development; flower, Alberta Agriculture, Food and Rural Development

Shepherd's-purse: seedling, Royer; juvenile, Hall; adult, Hoar; flower, Hoar

Stinkweed: seedling, Holm; juvenile, Hoar; adult, Hoar; flower, Hoar

Stork's-bill: seedling, Alberta Agriculture, Food and Rural Development; juvenile, Morrison; adult, Alberta Agriculture, Food and Rural Development; seed pods, Hoar

Yellow whitlow-grass: seedling, Hoar; juvenile, Hoar; adult, Hoar; flower, Hoar 


\section{Introduction}

his booklet is a simple field guide for identifying winter annual weeds commonly found in agricultural fields in Alberta. The weeds are listed in alphabetical order by their common names. Four photos are provided for each weed, showing the seedling, juvenile plant, adult plant and flower.

\section{What are winter annual weeds?}

Winter annuals germinate in the fall, overwinter (usually as small rosettes), then flower and produce seeds in the spring or early summer of the following year. Their overwintering form hugs the ground, enabling them to gain maximum advantage from the insulating effect of snow cover for protection against cold temperatures and drying winds. The rapid development of the flowering shoot (called bolting) in the spring gives winter annuals a competitive advantage over the crop.

Some of the weeds listed in this booklet commonly exist as winter annuals. Others may follow an annual or winter annual life cycle, depending on when they germinate. If they germinate late in the growing season and winter halts their growth before flowering, they may survive and grow again in spring. Still others occur as biennials or short-lived perennials under the right conditions.

\section{Controlling winter annual weeds}

Winter annual weeds can be a significant problem in reduced tillage and direct seeding systems. However, most can be effectively controlled if they are identified in fall or early spring. Several Alberta Agriculture publications provide information on controlling winter annual weeds including: Winter Annual Weed Control (Agdex 519-5), Crop Protection with Chemicals (the "blue book," Agdex 606-1), and Practical Crop Protection (the "green book," Agdex 606-3).

\section{Weed identification}

The descriptions in this booklet are short and simple. A few technical terms are used; they are defined in the glossary. Many of the terms relate to leaf characteristics. Leaf shape and arrangement are usually the most useful characteristics for identifying weeds, especially for plants in the seedling stage. The leaf collar is the only useful characteristic for identifying grasses in the seedling and juvenile stages.

Alberta Agriculture's Weeds of the Prairies (Agdex 640-4) provides more comprehensive coverage of agricultural weeds while the Weed Seedling Guide (Agdex $640-9$ ) is a handy guide for distinguishing between similar seedlings. 


\section{Clossary}

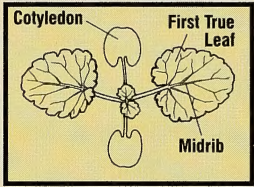

Annual - a plant which germinates, produces seeds and dies within one year.

Biennial - a plant which germinates in the spring or summer, overwinters as a small plant or rosette, and then in the spring matures, flowers and produces seeds.

Bracts - the small leaves or scales which may be found at the base of the flower head.

Clasping leaf - the leaf's base appears to partially or entirely wrap around the stem.

Cotyledons - the first seed leaves to emerge following germination.

Inflorescence - the flowering part of the plant, including the seed head.

Leaf collar - the part of a grass leaf between the blade (the expanded, usually flat, part of the leaf) and the sheath (the lower part of the leaf that surrounds the stem or shoot).

\section{Leaf position}

alternate - leaves are arranged one per node.

opposite - leaves are arranged two per node, on opposite sides of the stem.

basal - leaves are attached to the base of the plant.

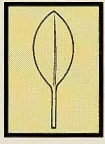

Ellipfic

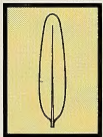

Lanceolate

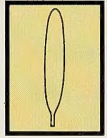

Linear

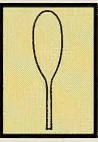

Obovate

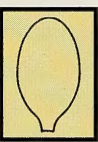

Oval

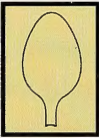

Ovate

\section{Leaf shape}

elliptic - lens-shaped.

entire - smooth margin which is not lobed, notched or wavy.

lanceolate - lance-shaped; leaf is longer than it is broad with the widest part at the base of the leaf.

linear - long and narrow, tapering at both ends.

oblong - paddle-shaped, rounded at the tip and sides nearly parallel.

obovate - egg-shaped with the widest part near the top of the leaf.

oval - rounded with the widest part at the centre of the leaf.

ovate - egg-shaped with the widest part near the base of the leaf.

Ligule - a flap of membranous tissue or fringe of hairs on the inside of a grass leaf where the blade joins the sheath (the leaf collar).

Midrib - the central vein or rib of a leaf.

Node - a joint or swollen part of the stem where leaves or branches are attached.

Rosette - a circular cluster of leaves arranged low to the ground.

Spikelet - the flowering unit of the grass inflorescence, composed of seeds and associated floral structures.

True leaves - all leaves which develop after the cotyledons. 


\section{Ball mustard}

(Neslia paniculata)

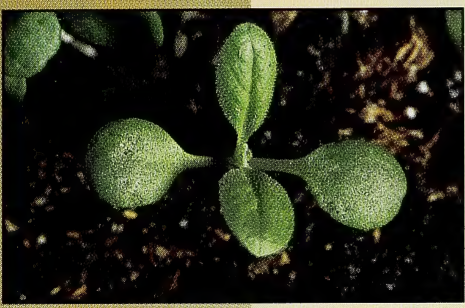

Seedling

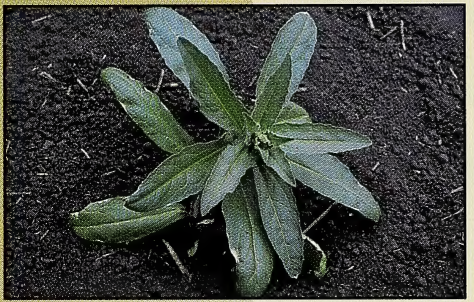

Juvenile

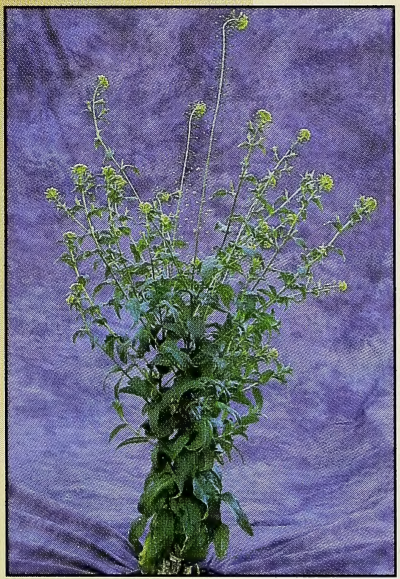

Adult

\section{Seedling}

Cotyledons are heart-shaped and hairless. True leaves are elliptic to oblong with pointed or rounded tips, and leaf bases taper to the stalk. Leaves and stems have small star-shaped hairs.

\section{Juvenile}

Young plant forms a rosette. Stem leaves are alternate, lance-shaped and clasp the stem.

\section{Adult}

Plant is erect with branched stems. Leaves are entire, wide, without prominent veins and softly hairy.

\section{Flower}

Flowers are small, yellow and four petaled. They are clustered near the end of the stems on stalks 6 to $10 \mathrm{~mm}$ long. Seed pods have a distinctive shape of a slightly flattened ball.

\section{Life cycle}

Annual or winter annual, reproducing by seed. Seeds remain viable in the soil for a few years.

\section{Location}

Most common in central and Peace regions of Alberta.

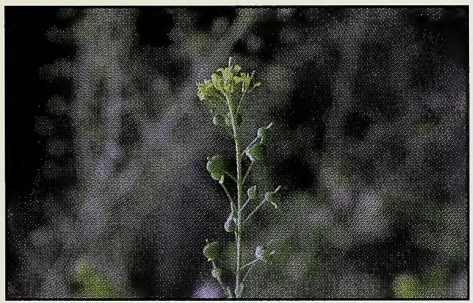

Flower 


\section{Bluebur}

\section{(Lappula echinata)}

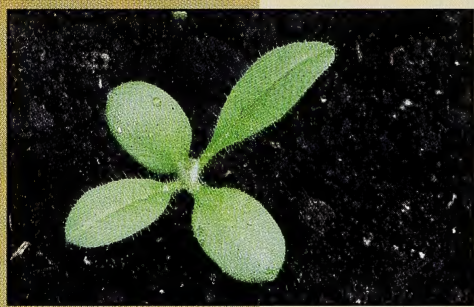

Seedling

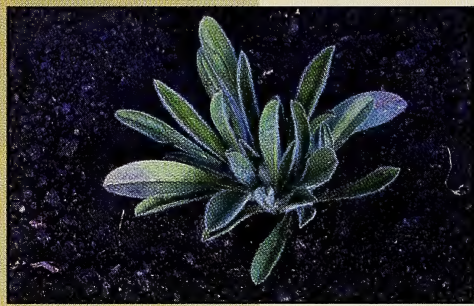

Juvenile

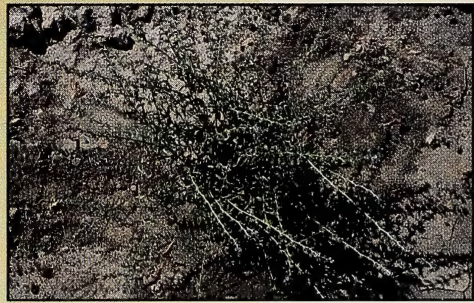

Adult

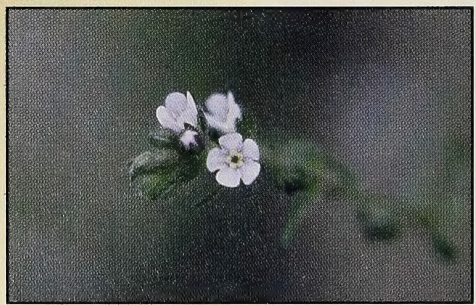

Flower

\section{Seedling}

Cotyledons are oval with short hairs. True leaves are hairy, oval and narrowing on both ends with a distinct crease down the centre.

\section{Juvenile}

Young plant forms a rosette of hairy leaves.

\section{Adult}

Leaves are alternate, gray-green and narrow. Stems are upright, much-branched and covered with stiff hairs. Plant has a characteristic mousy smell.

\section{Flower}

Flowers are small and pale blue. Petals are fused into a five-lobed flower. Seed pods have hooked spines which allow easy distribution on animal hair and clothing.

\section{Life cycle}

Annual or winter annual, reproducing by seed. Seeds remain viable for a few years.

\section{Location}

Found throughout Alberta. 


\section{Chidweed}

\section{(Stellaria media)}

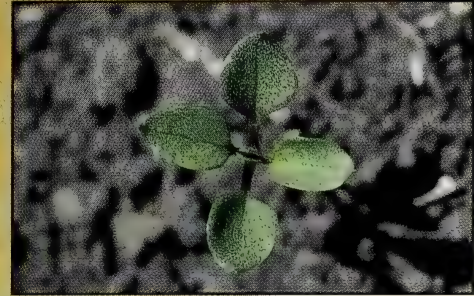

Seedling

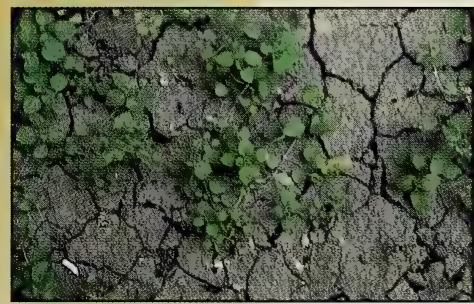

Juvenile

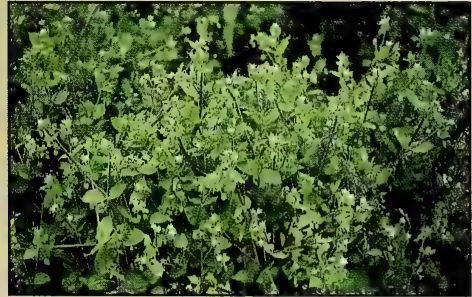

Adult

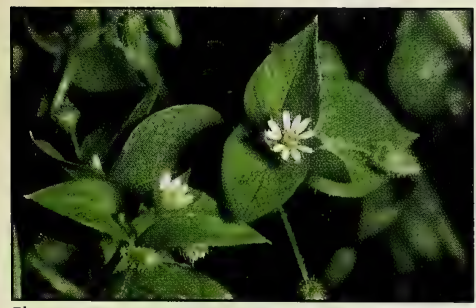

Flower

\section{Seedling}

Cotyledons and true leaves of this tiny seedling are oval with a pinched tip.

\section{Juvenile}

Leaves are opposite and attached to the main stem by a short, hairy stalk.

\section{Adult}

Stems are weak and have a line of hairs along one side. Plants can form a dense mat.

\section{Flower}

Flowers are inconspicuous, white and star-shaped.

\section{Life cyde}

Annual or winter annual, reproducing by seed and creeping stems which may root. Seeds remain viable in the soil for more than 60 years.

\section{Location}

Found throughout Alberta with the exception of the Brown soil zone. 


\section{Common groundsel}

(Senecio vulgaris)

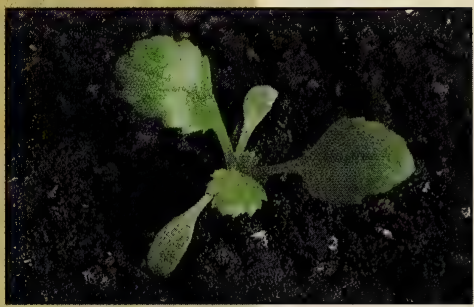

Seedling

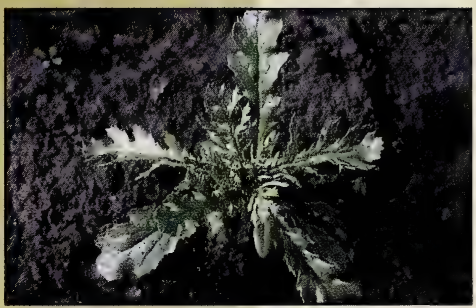

Juvenile

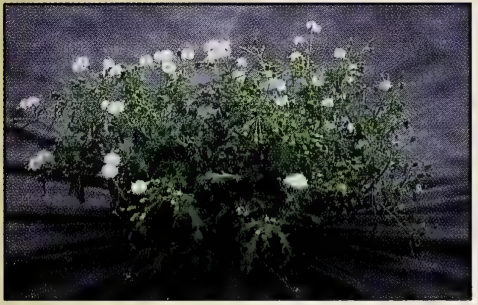

Adult

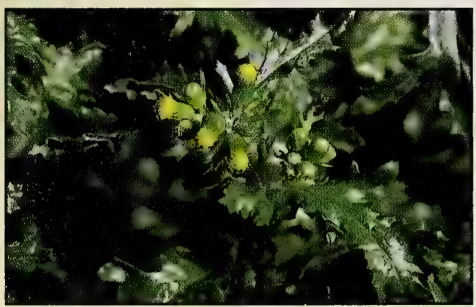

Flower

\section{Seedling}

Cotyledons are spoon-shaped with a groove at the base. True leaves are oval and stalked with a toothed margin.

\section{Juvenile}

Young plant forms a rosette. Leaves are alternate. Lower leaves are stalked. Upper leaves clasp the stem and are deeply lobed.

\section{Adult}

Plant bolts in early spring, forming a low, much-branched, hollow-stemmed adult. Leaves on the stem are stalkless.

\section{Flower}

Small, yellow, vase-shaped flowers are surrounded by smooth green bracts almost the same height as the flowers. Small dandelion-like plume is attached to the seed.

\section{Life cyde}

Annual or winter annual, reproducing by seed. Seeds remain viable in the soil for a few years.

\section{Location}

Found throughout Alberta. 


\section{Common pepper-grass}

(Lepidium densiflorum)

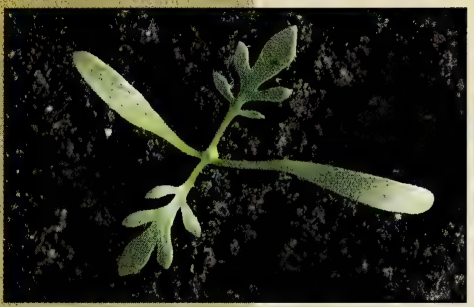

Seedling

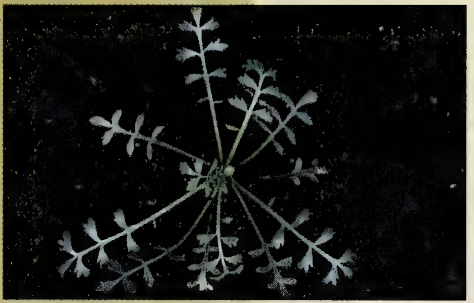

Juvenile

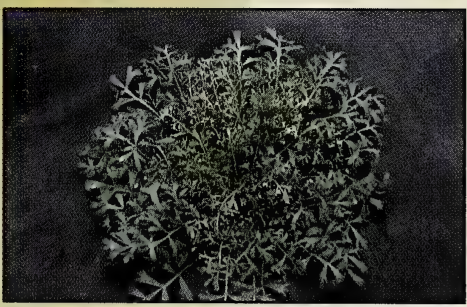

Adult

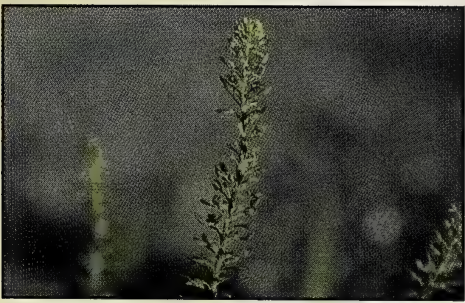

Flower

\section{Seedling}

Cotyledons are linear. True leaves are divided into linear lobes.

\section{Juvenile}

Young plant forms a rosette of deeply divided leaves.

Stem leaves are lanceolate with a few coarse teeth.

\section{Adult}

Stems are erect, much-branched and 15 to $60 \mathrm{~cm}$ high.

\section{Flower}

White, inconspicuous flowers are numerous and borne on short stalks. Seed pods are small, flattened and heart-shaped with a notch at the top.

\section{Life cycle}

Annual or winter annual, reproducing by seed.

\section{Location}

Found throughout Alberta. 


\section{Dog mustard (Erucastrum gallicum)}

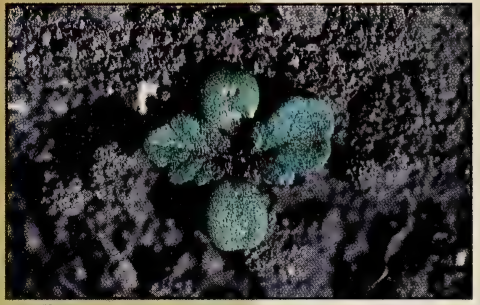

Seedling

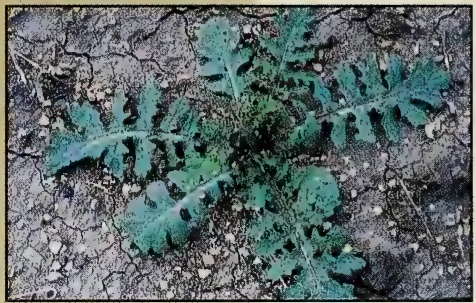

Juvenile

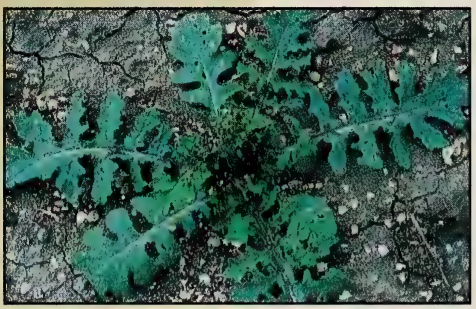

Adult

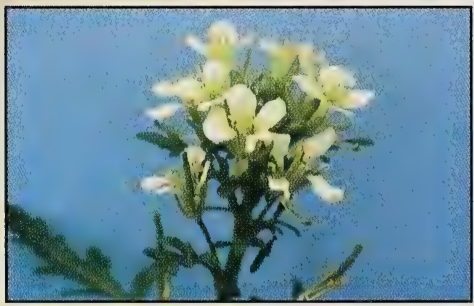

Flower

\section{Seedling}

Cotyledons are oval with an indentation at the tip.

True leaves are hairy with toothed margins.

\section{Juvenile}

Leaves are alternate, one per node, deeply lobed with wavy margins and covered with stiff hairs.

\section{Adult}

Stems are erect, simple to much-branched and covered with stiff hairs.

\section{Flower}

Flowers are clustered at the end of branched stalks. Seeds are borne in long pods.

\section{Life cycle}

Annual or winter annual, reproducing by seed. Seeds remain viable for a few years.

\section{Location}

Distribution in Alberta is unknown. 


\section{Downy brome}

\section{(Bromus fectorum)}

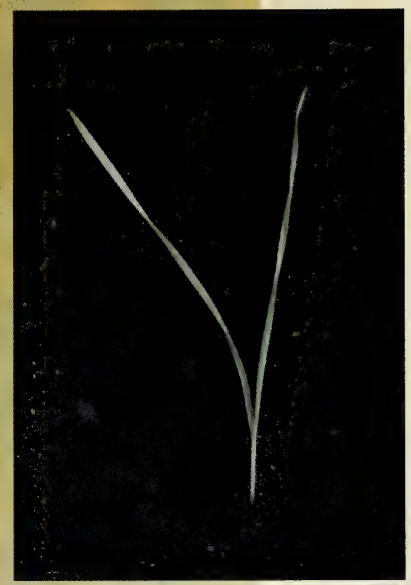

Seedling

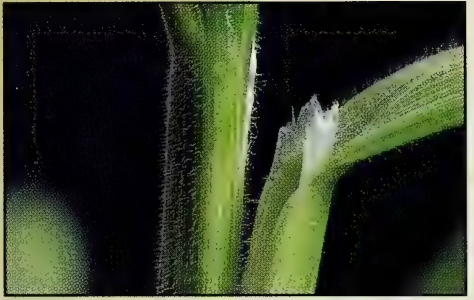

Leaf collar of juvenile

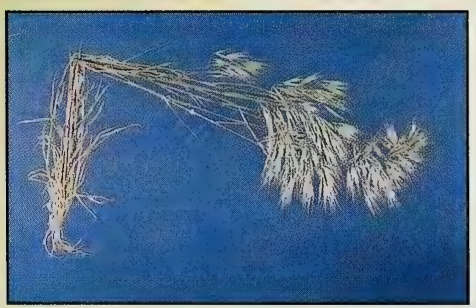

Adult

\section{Seedling}

Leaves are tall, narrow, twisted and covered in short hairs.

\section{Juvenile}

Leaf blades are softly hairy with prominent midribs. Ligule of leaf collar is $3 \mathrm{~mm}$ tall with a toothed margin (see drawing).

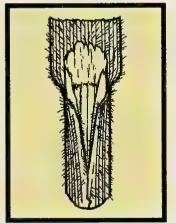

\section{Adult}

Stems are round, hollow, with swollen nodes and densely covered in soft, straight hairs.

\section{Flower}

Inflorescence is much-branched with spikelets at the ends of long and usually drooping branches. Heads are often purplish in colour.

\section{Life cycle}

Winter annual, reproducing by seed. Seeds remain viable in the soil for two to five years.

\section{Location}

Found mainly in southwestern Alberta.

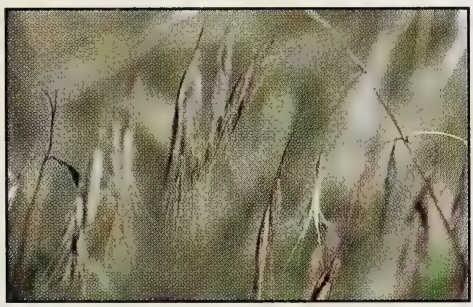

Flower 


\section{Flixweed}

\section{(Descurainia sophia)}

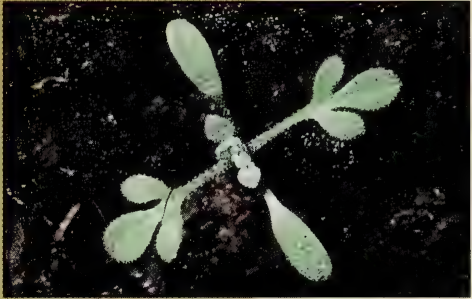

Seedling

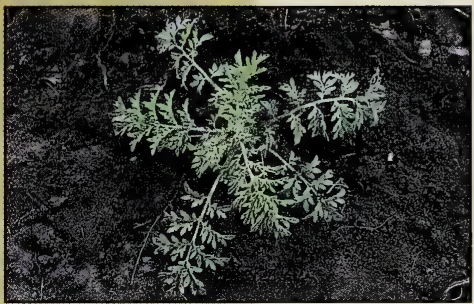

Juvenile

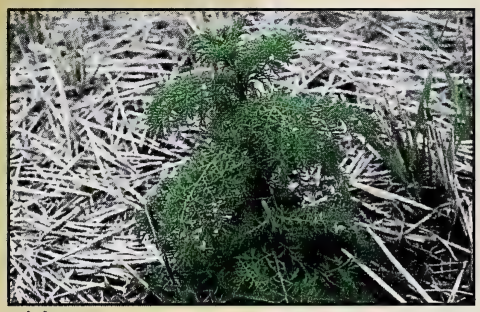

Adult

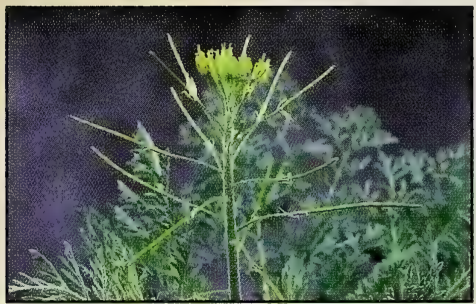

Flower

\section{Seedling}

Cotyledons are oblong. First true leaves are tri-lobed. Following leaves are finely divided. Seedling is easily confused with scentless chamomile and tansy mustard seedlings. However, flixweed cotyledons have a stalk whereas scentless chamomile cotyledons do not. Tansy mustard cannot be distinguished from flixweed at this stage.

\section{Juvenile}

Leaves are alternate, stalked, finely divided and covered with fine hairs.

\section{Adult}

Plant is grey-green. Erect, branched stems may have star-like hairs.

\section{Flower}

Flowers have four small, pale yellow petals. Pods are long. Seeds are located on one side of the pod, not on both sides as for most other mustards.

\section{Life cycle}

Annual or winter annual, reproducing by seed. Seeds remain viable for more than three years.

\section{Location}

Found throughout Alberta. 


\section{Knawel}

(Scleranthus annuus)

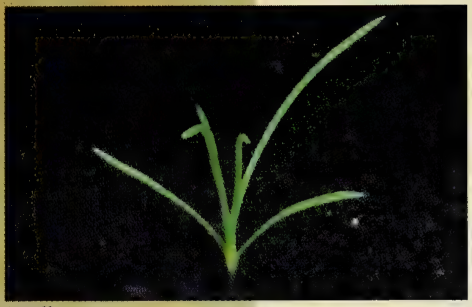

Seedling

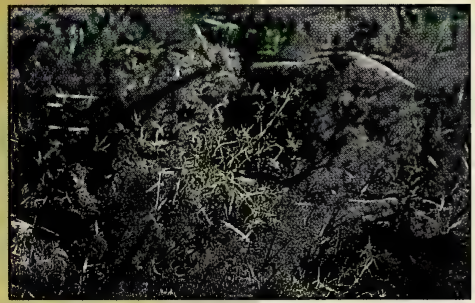

Juvenile

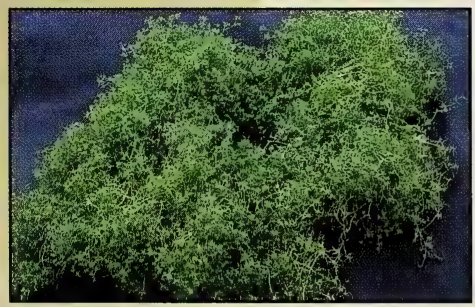

Adult

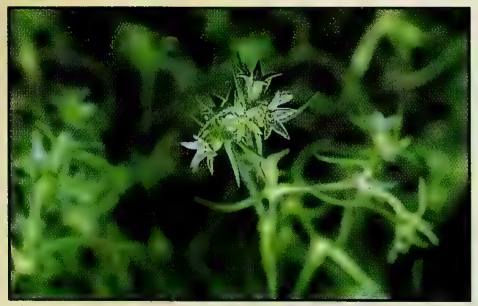

Flower

\section{Seedling}

Cotyledons are linear. True leaves are needle-like, curving down at the tips. Seedling is similar to corn spurry and Russian thistle. Leaves lack the needle tip of Russian thistle. Leaves occur in pairs, unlike corn spurry leaves which occur in a whorl around the stem.

\section{Juvenile}

Needle-like leaves are stalkless and arranged in pairs on opposite sides of the stem with hairs near the base.

\section{Adult}

Stems are weak, spreading and much-branched at the base with swollen nodes.

\section{Flower}

Flowers are small and green, and occur in small groups at the bases of the upper leaves.

\section{Life cycle}

Annual, winter annual or biennial, reproducing by seed.

\section{Location}

Found throughout Alberta. 


\section{Narrow-leaved hawk's-beard}

(Crepis tectorum)

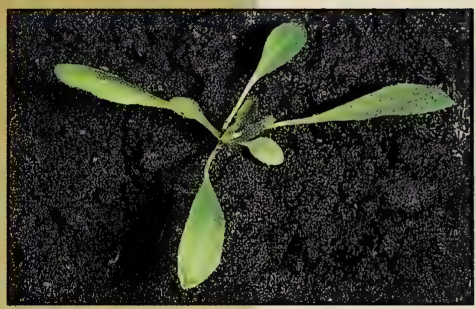

Seedling

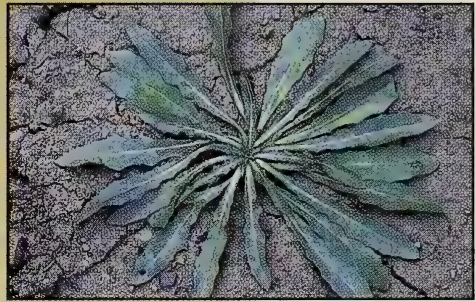

Juvenile

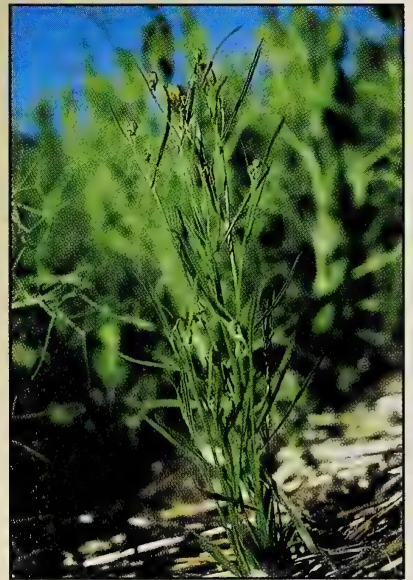

Adult

\section{Seedling}

Cotyledons are oval and hairless. True leaves are oval to lanceolate with several small, downward-pointing teeth.

\section{Juvenile}

Young plant forms a rosette. Basal leaves are long and narrow. Leaves are attached directly to the stem.

\section{Adult}

Mature plant is erect. Slender, branched, leafy stems have milky white sap. Leaves often roll under. Plant is sometimes confused with annual sow-thistle, perennial sow-thistle or prickly lettuce. However, narrow-leaved hawk's-beard has narrow, entire leaves, whereas annual and perennial sow-thistle do not. Prickly lettuce leaves have sharp bristles on the underside midrib, while narrow-leaved hawk's-beard leaves do not.

\section{Flower}

Flowers are yellow, dandelion-like, and surrounded by green, hairy bracts. Flowers are clustered together.

\section{Life cycle}

Annual or winter annual, reproducing by seed.

\section{Location}

Found mainly in central and northern Alberta.

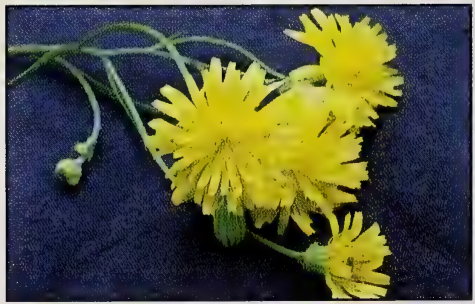

Flower 


\section{Night-flowering catchily \\ (Silene noctiflora)}

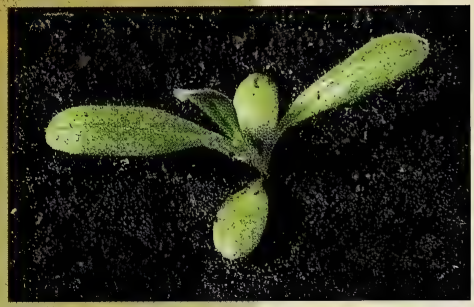

Seedling

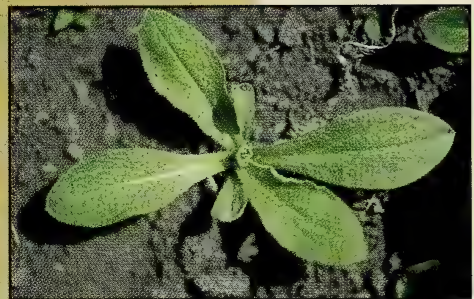

Juvenile

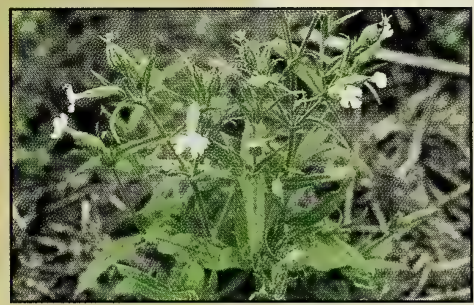

Adult

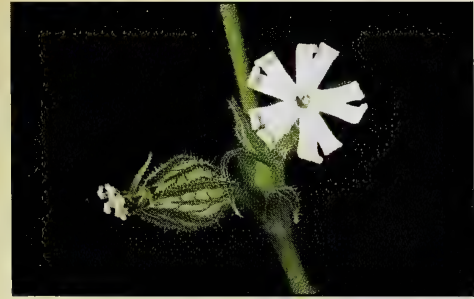

Flower

\section{Seedling}

Cotyledons are oblong to oval and fringed with hairs at the base. True leaves are opposite, spoon-shaped, and covered with sticky hairs. Seedling can be confused with bluebur and white cockle seedlings. However, night-flowering catchfly feels sticky while cow cockle and bluebur do not.

\section{Juvenile}

Young plant has short-stalked basal leaves and stalkless upper leaves.

\section{Adult}

Leaves are opposite. Plant has one to three stems, sparingly branched, with sticky hairs and swollen nodes.

\section{Flower}

Flowers are white or occasionally pinkish, with five divided petals topping a bulbous green base. Base has 10 veins, five of which are very distinct. Flowers usually open in the evening.

\section{Life cycle}

Annual or winter annual, reproducing by seed. Seeds remain viable in the soil for longer than three years.

\section{Location}

Found throughout Alberta. 


\section{Pygmyilower \\ (Androsace septentrionalis)}

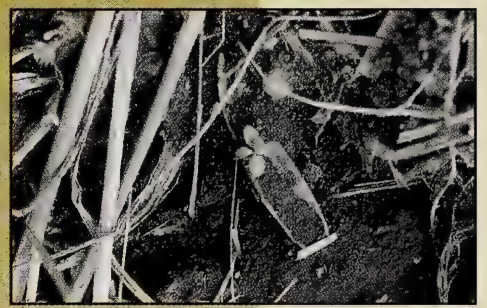

Seedling

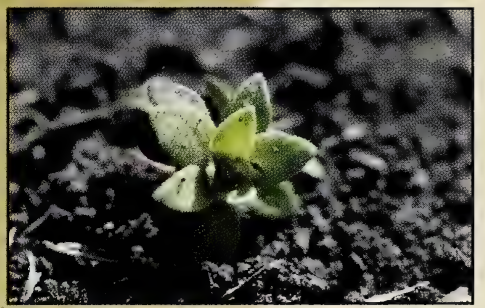

Juvenile

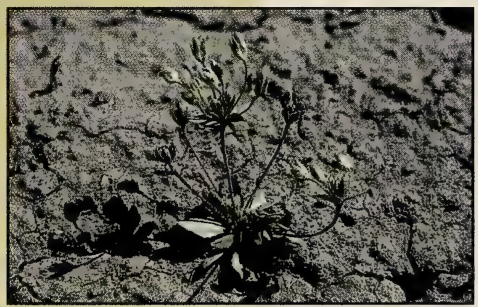

Adult

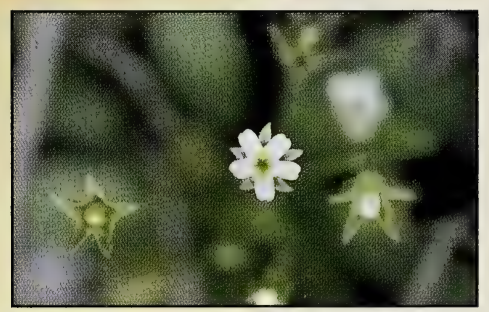

Flower

\section{Seedling}

Seedling is very small and rarely seen.

\section{Juvenile}

Young plant forms a rosette.

\section{Adult}

A tiny plant. Leaves are elliptic and form a basal rosette with a few flowering stems.

\section{Flower}

Small white or pinkish flowers occur in a cluster at the top of a stalk.

\section{Life cycle}

Winter annual, reproducing by seed.

\section{Location}

Found on eroded, dry soils, stubble fields and cultivated land early in the spring. 


\section{Scentless chamomile}

(Matricaria maritima)

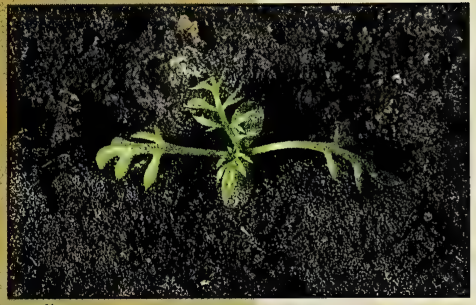

Seedling

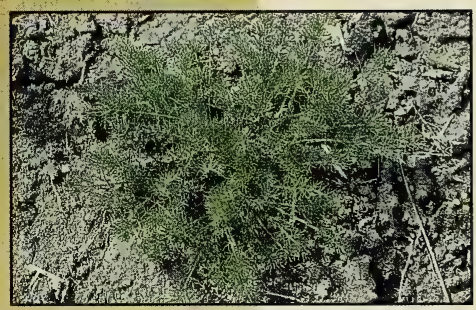

Juvenile

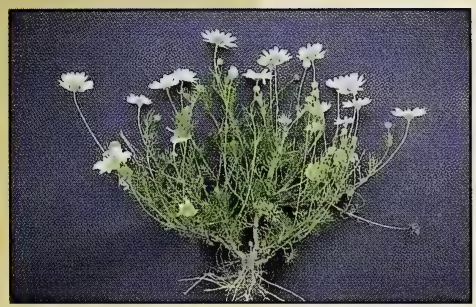

Adult

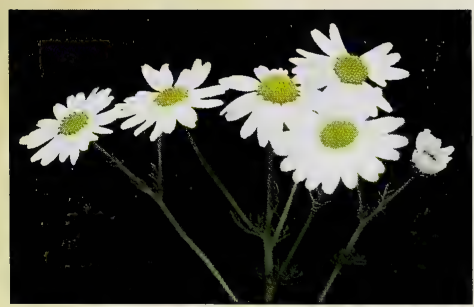

Flower

\section{Seedling}

Cotyledons are oval and attached directly to the stem. True leaves are carrot-like: deeply and finely divided.

\section{Juvenile}

Young plant forms a compact clump with finely divided leaves. At this stage it can be confused with pineappleweed. However, crushed leaves of pineappleweed have a distinct pineapple odour.

\section{Adulf}

Mature plant is erect, with a much-branched, hairless stem.

\section{Flower}

Flowers are showy and daisy-like with white petals arranged around yellow centres.

\section{Life cycle}

Annual, winter annual or short-lived perennial, reproducing by seed.

\section{Location}

Found throughout Alberta, particularly where solonetzic soils occur. 


\section{Shepherd's-purse}

\section{(Capsella bursa-pastoris)}

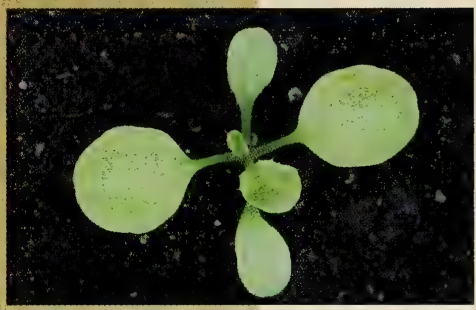

Seedling

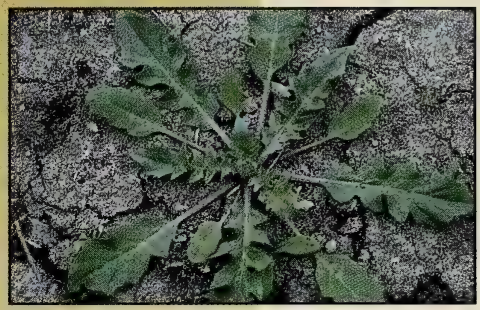

Juvenile

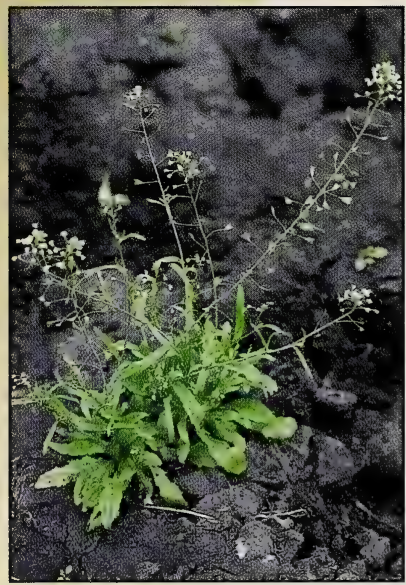

Adult

\section{Seedling}

Cotyledons are usually oval and stalkless, but leaf shape is variable. First true leaves are oval to elliptic with short stalks.

\section{Juvenile}

Young plant forms a rosette. Basal leaves are deeply lobed with branched hairs on the surface.

\section{Adult}

Mature plant has an erect, branched stem covered in gray hairs. Stem leaves are clasping and linear, and may be toothed.

\section{Flower}

Flowers are small and white with four petals. They are borne singly on short stalks and are clustered at the end of stems. Seed pods are flattened and triangular with a deep notch at the top.

\section{Life cycle}

Annual or winter annual, reproducing by seed.

\section{Location}

Found throughout Alberta.

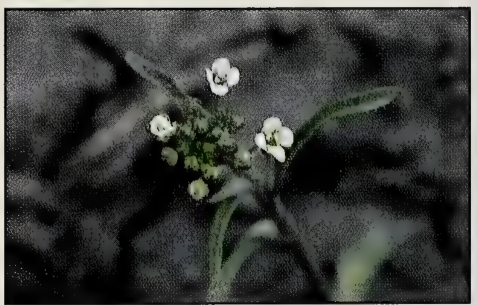

Flower 


\section{Stinkweed \\ (Thlaspi arvense)}

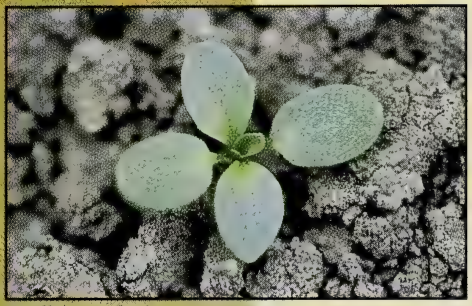

Seedling

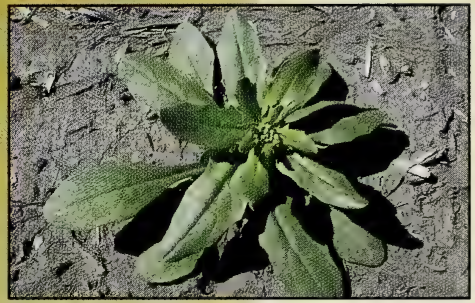

Juvenile

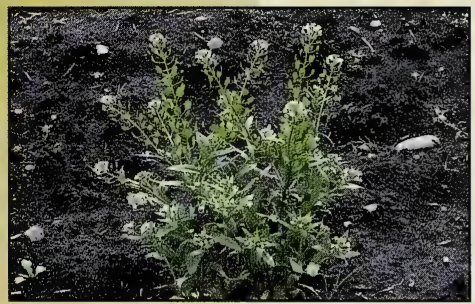

Adult

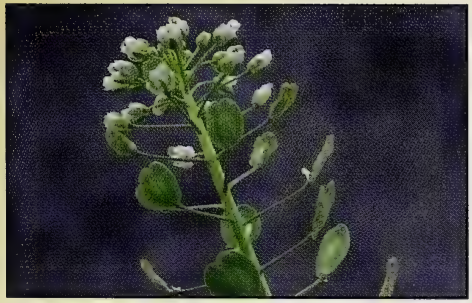

Flower

\section{Seedling}

Cotyledons are oval and hairless. True leaves are oblong with stalks and usually have smooth, wavy edges, but shape is variable.

\section{Juvenile}

Leaves are usually in a basal rosette. Stem leaves are smaller than basal leaves, stalkless, and clasp the stem.

\section{Adult}

Mature plant has an erect stem. Stinkweed can be distinguished from shepherd's-purse by its hairless leaves and its smell.

\section{Flower}

Flowers have four white, pinkish or lavender petals. Flowers occur in clusters at the end of branches. Seed pods are flattened, notched circles.

\section{Life cycle}

Annual or winter annual, reproducing by seed.

\section{Location}

Found throughout Alberta. 


\section{Stork's-bill}

(Erodium cicutarium)

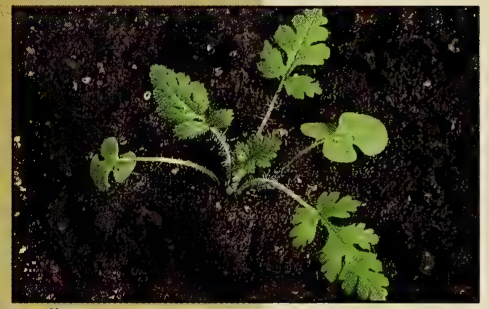

Seedling

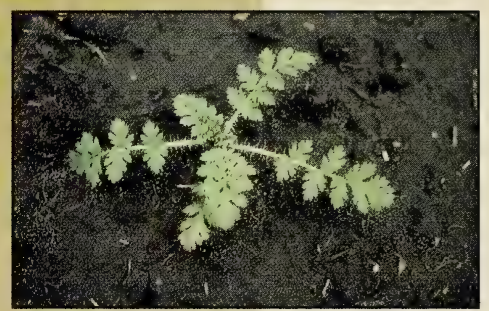

Juvenile

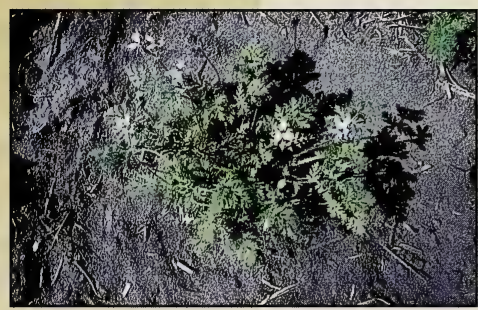

Adult

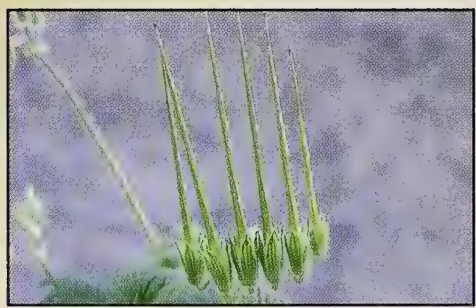

Flower

\section{Seedling}

The only weed seedling with tri-lobed cotyledons. True leaves are finely divided.

\section{Juvenile}

Young plant is hairy and forms a rosette. Leaves are divided into feathery leaflets.

\section{Adult}

Mature plant has flowering stems which are low and spreading, with few leaves.

\section{Flower}

Flowers are small ( $1 \mathrm{~cm}$ diameter) and pink-purple. They form in clumps on long stalks. Seed pod has a distinctive shape: $5 \mathrm{~mm}$ long with a long tail which is coiled when dry.

\section{Life cycle}

Annual or winter annual, reproducing by seed.

\section{Location}

Found throughout Alberta. 


\section{Yellow whiflow-grass}

\section{(Draba nemorosa)}

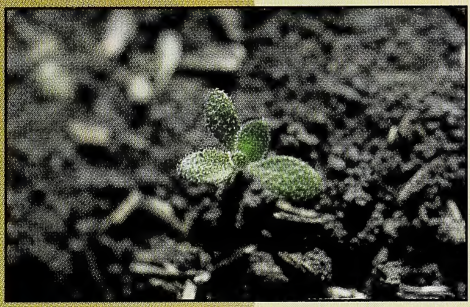

Seedling

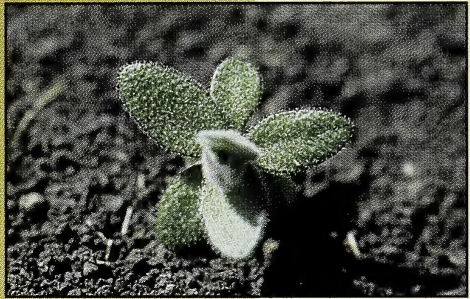

Juvenile

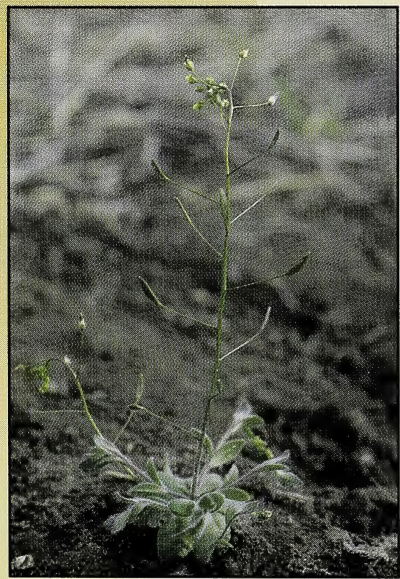

Adult

\section{Seedling}

Cotyledons are small and obovate. True leaves are elliptic to ovate and covered in short hairs.

\section{Juvenile}

Young plant forms a rosette of hairy leaves.

\section{Adult}

Tiny, low plant branches from a rosette of basal leaves.

\section{Flower}

Flowers are pale yellow or occasionally white and appear in early spring.

\section{Life cyde}

Winter annual, reproducing by seed.

\section{Location}

Fairly common in southern Alberta.

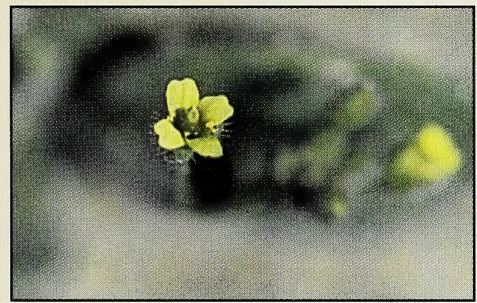

Flower 


National Library of Canada Bibliothèque nationale du Canada 